\title{
Armas para las Indias. El problema del suministro de armas y la defensa colonial durante el reinado de Carlos II
}

\author{
Antonio Espino López ${ }^{1}$
}

Recibido: 6 de abril de 2018 / Aceptado 8 de marzo de 2019

Resumen. En el presente trabajo nos hemos interesado por la problemática de la reposición en las Indias de armas de fuego portátiles, artillería y municiones durante el reinado de Carlos II. Una cuestión que no siempre fue fácil de resolver, ni a la que se le daba salida, a menudo, de un modo eficiente y rápido. Una Monarquía en plena decadencia hubo de ingeniárselas para acompasar los pedidos llegados de Ultramar con los recibidos desde las diversas fronteras europeas y norteafricanas. No fue tarea fácil, pues, a menudo, las discusiones acerca de la remisión de las armas y las municiones necesarias para utilizarlas escapaban al ámbito del Consejo de Indias, de la Junta de Guerra de Indias, y acababan siendo materia de reflexión por parte del Consejo de Guerra (y del de Estado), sobre todo en los años en los que había guerra en Europa. Para poder alcanzar algunas conclusiones, se ha debido analizar, por lo tanto, documentación depositada en el Archivo de Indias (Sevilla), el General de Simancas (Valladolid) e, incluso, el Histórico Nacional de Madrid. Se puede concluir que durante el reinado del último de los Austrias, las dificultades económicas lastraron enormemente el normal y correcto funcionamiento de las fábricas de armas y municiones de la Monarquía que, habitualmente, contrataban sus producciones bajo el sistema de asiento. De ahí que la remisión de armas a América sufriera continuos retrasos, sin contar con la necesidad de que desde los propios virreinatos se contribuyese a la fabricación y reparto de las mismas.

Palabras clave: Armas de fuego; municiones; fábricas de armas; artillería; asientos; Indias; Monarquía Hispánica; Carlos II; siglo XVII.

\section{[en] Arms for the Indies. The problem of weapons supply and colonial defense during the reign of Charles II}

\begin{abstract}
This article deals with the problem of replacing portable firearms, artillery and ammunition in the Indies during the rule of Charles II - an issue that wasn't always easily resolved nor frequently dispatched in a rapid or efficient manner. A monarchy in full decline had to ingeniously manage and pace the demands from overseas territories with those of the different European and North-African frontiers. The task was not an easy one since the debates regarding the remission of arms and the ammunition necessary to use them, went beyond the scope of the Council of the Indies and the War Board of the Indies, and ended up being matters of consideration at the Council of War (and the Council of State), especially during years of war in Europe. In order to reach some conclusions, it was therefore necessary to analyse documentation at the Archivo de Indias (Seville), the Archivo General de Simancas (Valladolid) and the Archivo Histórico Nacional (Madrid). In conclusion, during the reign of the last Habsburg monarch, economic difficulties enormously hindered the normal and correct functioning of the arms and ammunitions factories of the Monarchy, which habitually contracted production through the asiento system. As a result, the remission of weapons to America would suffer continuous delays,
\end{abstract}

1 Universidad Autónoma de Barcelona (España)

E-mail: Antonio.Espino@uab.cat 
without taking into consideration the possibility of the Viceroyalties, themselves, contributing to the production and distribution of arms.

Keywords: Firearms; Ammunition; Arms factories; Artillery; Monopolies; Indies; Hispanic Monarchy; Charles II; 17th century.

Sumario. 1. Introducción. 2. Armas de fuego portátiles. 3. Artillería. 4. Conclusiones. 5. Referencias bibliográficas.

Cómo citar: Espino López, A. (2019) Armas para las Indias. El problema del suministro de armas y la defensa colonial durante el reinado de Carlos II, en Revista Complutense de Historia de América 45, 189-210.

\section{Introducción}

Una de las constantes tanto de los ejércitos que luchaban en Europa como de las fuerzas que defendían las Indias fue la necesidad de reponer las armas y municiones consumidas a lo largo del tiempo ${ }^{2}$. Una cuestión que no siempre fue fácil de resolver, ni a la que se le daba salida, a menudo, de un modo eficiente y rápido. Las demandas de compra de armas llegaban habitualmente a la Junta de Guerra de Indias, o bien se discutían tras derivarse al mismo en el Consejo de Guerra, pues se trataba de acompasar los pedidos de Ultramar con los recibidos desde las diversas fronteras europeas y norteafricanas de la Monarquía de Carlos II. Lo cierto es que durante el reinado del último de los Austrias, las dificultades económicas lastraron enormemente el normal y correcto funcionamiento de las fábricas de armas y municiones de la Monarquía que, habitualmente, contrataban sus producciones bajo el sistema de asiento. Junto a la fundición de artillería de bronce de Sevilla ${ }^{3}$ no debemos olvidar las factorías cántabras de Liérganes y La Cavada ${ }^{4}$, si bien se fabricó armamento, y con larga tradición, en Cataluña (sobresale Ripoll), Milán, Plasencia y otros lugares. Las fábricas de pólvora se localizaban en Tolosa, Granada, Alcázar de San Juan o Murcia, aunque también se traía de Italia (Milán o Nápoles), e incluso importada de las Provincias Unidas. Otros lugares, como Málaga, donde se habían fundido cañones a lo largo del siglo XVI, estaban en plena decadencia en los años de Carlos II.

En las Indias llegó a haber fundición de artillería en La Habana, aunque se ordenó su cierre y el traslado de su personal a Sevilla en $1607^{5}$. En Filipinas se trató sobre la necesidad de contar con un fundidor y un polvorista desde 1587 al menos ${ }^{6}$, mientras que en Nueva España hubo fundiciones en Acapulco y Chapultepec, si bien en Perú

2 Sin ánimo de ser exhaustivos, para comparar las dificultades del envío de armas a las Indias con respecto a otras fronteras hispánicas, pueden consultarse con provecho: Ribot, 2002; Requena, 1997; Thompson, 1981 y 2012 ; Usunáriz, 2007; Mesa, 2012; Echevarría, 2006. Sobre, por ejemplo, las dificultades de los ejércitos de Luis XIV, véanse, por ejemplo: Lynn, 1998; Rowlands, 2002; Ayats, 2002; Cénat, 2010.

3 Aunque centrado en el siglo XVIII, es de obligada lectura la tesis de Aguilar Escobar, 2008. Además, el trabajo pionero de Serrano Mangas, 1984.

$4 \quad$ Sobre la fábrica de Liérganes, véase Alcalá-Zamora, 1974.

5 Real Cédula. Madrid, 17-XII-1607. Archivo General de Indias [España] (en adelante AGI), Santo Domingo, leg. 869-5.

6 Consulta del Consejo de Indias (en adelante CI). Madrid, 18-IX-1609. AGI, Filipinas, leg. 36-40. En 1611, la fundición de Manila se trasladó al Fuerte Viejo. Consulta del CI. Madrid, 17-VII-1611. AGI, Filipinas, leg. 29107. 
se fundieron muchas más piezas al contar con el cobre chileno de Coquimbo y el estaño del propio Perú. Desde Nueva España se consultó con el virrey de Perú, IV marqués de Cañete (1590-1596), quien aseguraba haber fundido nada menos que ciento cuarenta piezas de treinta a sesenta quintales y dos culebrinas de noventa quintales. Por otro lado, desde Lima se enviaban piezas a Arica, Guayaquil y otros puertos, así como a Acapulco, y a Manila desde allá si hiciese falta ${ }^{7}$. Pero el virrey de Nueva España, don Luis de Velasco, en el transcurso de su segundo mandato (1607-1611) intentó convencer a la Junta de Guerra de Indias sobre las bondades, y los precios, de los materiales necesarios para fundir y fabricar pólvora en las propias Filipinas, siempre que se pudiese enviar allá a algún técnico ${ }^{8}$.

En el presente trabajo nos vamos a interesar, pues, por el suministro de armas remitidas desde la Península a las Indias durante el reinado de Carlos II, incluyendo la fabricación y la distribución interna llevada a cabo por los diversos virreyes americanos. Se ha utilizado, contrastándola, documentación de los Consejos de Indias, Estado y Guerra depositada en los Archivos de Indias y General de Simancas. De esta forma podemos analizar en toda su extensión cómo los diversos Consejos de la Monarquía detectaban, trataban, consultaban y buscaban soluciones para una problemática tan difícil cuando el dinero escaseaba como era la de la defensa. Pues, a menudo, las discusiones acerca de la remisión de las armas y las municiones necesarias para utilizarlas escapaban al ámbito del Consejo de Indias, de la Junta de Guerra de Indias, y acababan siendo materia de reflexión por parte del Consejo de Guerra (y del de Estado), sobre todo en los años en los que había guerra en Europa.

\section{Armas de fuego portátiles}

El virrey de Nueva España, marqués de Mancera (1664-1673), como era habitual, hubo de ocuparse del rearme de los presidios bajo su administración como una de sus primeras tareas ineludibles. En febrero de 1665 informaba sobre no haber podido satisfacer el encargo del gobernador de La Habana en cuanto al envío de quinientos arcabuces -aunque sí le remitió pólvora, cuerda, salitre y plomo- "porque no los ai (sic)". También el gobernador de Filipinas había demandado otros mil quinientos arcabuces vizcaínos y milaneses, las dos manufacturas más apreciadas, y quinientos mosquetes. Es más,

Y son tan continuos los socorros que piden destas armas para todas las plaças de las yslas de Barlovento que es ymposible poderlos haçer deste reyno, y quando se quisieron labrar en el fue a mucha costa por la que tiene el fierro y los oficiales, y no se labran como son menester haviendo costado los que se han hecho otras veces a veinticinco y a treinta pesos $[\ldots]^{9}$.

\footnotetext{
7 "Lo que dice el sr. marqués de Cañete sobre lo que se le preguntó acerca de la artillería del Perú". ¿Madrid?, s. f. AGI, México, leg. 27-35.

8 Consulta de la Junta de Guerra de Indias. Madrid, 23-IX-1608. AGI, México, leg. 27-35.

9 Virrey Mancera a Felipe IV. México, 17-II-1665, AGI, México, leg. 40-10. Por cierto, que en noviembre de 1666 en una minuta del Consejo de Indias se aseguraba que "aun para las partes más precisas de España no había armas en las fábricas”, y todo apunta a que la petición del gobernador de Filipinas, trasladada a otros lugares por si las tenían de sobra, no se satisfizo. Consulta del CI. Madrid, 11-X-1666 y respuesta final de noviembre de 1666. AGI, Filipinas, leg. 2-242
} 
Así, el coste de ambas remesas se iría a medio millón de reales, como mínimo, cuando en la armería de Ciudad de México apenas si quedaban ciento diez arcabuces de cuerda, es decir de mecha, setenta mosquetes y sesenta y dos carabinas ${ }^{10}$. En consecuencia, y habida cuenta de la cercanía de los ingleses a Veracruz, pues en quince días de navegación desde Jamaica estaban sobre ella, el virrey encargó ese mismo año la compra de dos mil arcabuces y un millar de mosquetes vizcaínos con sus complementos -frascos, frasquillos, horquillas- por un valor de 268.000 reales al asentista Baltasar de Resusta, pero Felipe IV no autorizó aquella adquisición ${ }^{11}$. El negocio era más complicado, pues Mancera había recibido 400.000 reales del conde de Lemos, virrey de Perú, para, asimismo, comprar armas, y quiso enviar a Resusta a conseguir parte de las mismas a España, pero otra parte se fabricarían en México a 144 reales cada arcabuz o mosquete -no los 200 o 240 reales que había referido antes-, cuando en la Península se obtenían por 80 reales. Lógicamente, se le dijo a Mancera que se enviasen los 400.000 reales a la Corte. Se tardó diez años en resolver el caso ${ }^{12}$. Pero lo habitual era que dichos encargos se tratasen en la Península y las armas se labrasen en ella, pues a la fama de ser muy cara su manufactura en Nueva España se añadía su falta de calidad y el mucho tiempo que se tardaba en satisfacer los encargos por no disponer de los medios fabriles apropiados en Ultramar ${ }^{13}$.

De todas partes llegaron encargos. En el caso de Chile, en 1665 el gobernador Juan Enríquez hizo una petición formal de armas para aquel Reino, que se le sirvieron en 1668, para poder cubrir las pérdidas habidas en el alzamiento aborigen de 1655: seiscientos arcabuces, trescientos mosquetes vizcaínos, doscientas carabinas, trescientos pares de pistolas, medio millar de granadas cargadas, quinientas hojas de espada ancha y un millar de puntas de pica y chuzo, así como todas las herramientas de zapador que se estimasen oportunas "para el ejército y para las poblaciones que se están haciendo". Una nueva remesa de armas habría de esperar, según la Junta de Guerra de Indias, a fines de 1669 o inicios de $1670^{14}$.

En 1666, llegó una demanda de armas para Guatemala (ochocientos arcabuces) con la excusa, totalmente creíble por otra parte, de evitar invasiones de ingleses desde Jamaica. El Consejo de Guerra, agobiado por los momentos finales de la guerra de Restauración portuguesa, señaló la dificultad casi insalvable para cubrir las necesidades armamentísticas de todos los ejércitos de la Monarquía en aquellos momentos, y las que pedía Guatemala no debían ser tan necesarias, aunque no explicitaron el porqué de tal aseveración. En cualquier caso, eran los consejeros del de Indias quienes deberían hacerse cargo del asunto y enviasen dinero para su fabricación y/o

10 Según el testimonio del duque de Alburquerque, bajo su administración, en 1658, se hizo un encargo consistente en mil arcabuces, setecientos cincuenta mosquetes y la misma cantidad de carabinas, todas las armas con sus complementos, con un valor de 146.500 reales de plata. Es decir, con un coste medio de 58,6 reales de plata. Las armas se enviaron desde España. Duque de Alburquerque a don Pedro de Medrano. Madrid, 31-V-1665. AGI, México, leg. 40-10. Pero según el virrey, conde de Baños, en enero de 1663 faltaban otra vez armas y solicitaba un envío de cinco mil arcabuces y tres mil mosquetes con sus complementos. Conde de Baños a Felipe IV. México, 8-I-1663 AGI, México, leg. 39-2.

11 Hanke - Rodríguez, 1978, v. V: 33.

12 Informe del fiscal del CI. Madrid, 12-III-1675. AGI, México, leg. 45-108.

13 Duque de Alva a don Pedro Medrano. Madrid, 31-V-1665. AGI, México, leg. 40-10.

14 Copias de cartas del gobernador Enríquez a Mariana de Austria, 1668, con consultas de la Junta de Guerra de Indias. Madrid, 9-IX-1668, 27-X-1668 y 20-XII-1668. AGI, Chile, leg. 23-8. 
compra, fue su respuesta final ${ }^{15}$. El problema añadido era que la Monarquía pretendía que se gastase el dinero destinado a la manufactura de armas en Europa en las fábricas de la Península si era posible -aunque en un momento dado se trajesen armas de Milán y municiones de Nápoles. Las armas se remitieron a Guatemala, pero solo en 1672 se enviaron un millar de frascos y frasquillos para aquellos arcabuces. Con dicho envío se recordó la necesidad de cubrir lo antes posible el pedido, con destino a La Guaira, en Venezuela, de otros doscientos arcabuces con sus complementos, treinta quintales de pólvora y veinte de cuerda y balería ${ }^{16}$. También se solicitaron hachas (trescientas), además de otras muchas herramientas para la reconstrucción de la plaza de Panamá, asolada aquellos años por H. Morgan, así como mosquetes de chispa (se iban a comprar cien, pero se precisaba un número mayor). Don Antonio de Córdoba, presidente de la Audiencia panameña, precisó que "respecto de las continuas lluvias de aquel reyno haze inútiles en muchas ocasiones a los de cuerda [...]", de ahí que se demandasen de chispa ${ }^{17}$.

Asimismo, ese último año se intentó dar curso al pedido por valor de 400.000 reales del virrey del Perú que, como vimos, el duque de Mancera intentó controlar de alguna manera. En concreto, se solicitaron dos mil arcabuces para Nueva Granada. El Consejo de Guerra informaba en julio que no se podía acudir a las fábricas de armas de Guipúzcoa por estar debiéndoseles nada menos que 1.100 .000 reales por armamento ya entregado. Sin algún adelanto de por medio, y sabiendo que había un pedido de tres mil mosquetes para Flandes pendiente de cumplir, la respuesta real fue clara: Nueva Granada se quedaría sin armas, mientras que el ejército de Flandes, donde eran más necesarias, las iría recibiendo poco a poco, puesto que la manufactura de las mismas era dificultosa por falta de fondos y por necesitarse armas en todas partes $^{18}$.

En realidad, la ruptura de la paz entre Francia e Inglaterra con las Provincias Unidas en 1672, lo que sería la guerra de Holanda (1672-1678) y la tercera guerra anglo-neerlandesa (1672-1674), colocó a la Monarquía Hispánica en una posición muy difícil con respecto a sus colonias. Una manera de demostrar dicho aserto es señalar la reiteración en la solicitud de armas. Las hubo para Santo Domingo y se recordó la necesidad de que la armada de Barlovento estuviese en disposición de defender aquellas aguas. El problema, como fue tan habitual aquellos años, era que las peticiones comenzaban a ser tratadas con demasiados meses de atraso. A veces años. El Consejo de Indias destinó 93.144 reales de plata para la manufactura de armas procedentes de las consignaciones de Nueva España. La orden le fue transferida a don Diego Sarmiento, general de la artillería de España, quien explicó en su momento cómo recibió aquella orden y la de conducir las armas a Cádiz, plaza que actuaba a la manera de almacén para todo el material de guerra a distribuir tanto para las Indias como para las plazas del norte de África, pero también, en un momento dado, para los Países Bajos o Cataluña. Sarmiento ya había recibido una orden previa, en 1670, reiterada en 1671, de servir armas con destino a la escuadra que se enviase a la recu-

15 Consulta del Consejo de Guerra (en adelante CG). Madrid, 8-X-1666. Archivo General de Simancas [España] (en adelante AGS) [España], Guerra Antigua (en adelante GA), leg. 2113.

16 Consulta del CG. Madrid, 20-VI-1672. AGS, GA, leg. 2268.

17 Consulta del CI. Madrid, 22-X-1672. AGI, Panamá, leg. 3-102.

18 Consulta del CG. Madrid, 13-VII-1672. AGS, GA, leg. 2268. 
peración de Panamá ${ }^{19}$, además de solicitarse otros 1.467 arcabuces para Cartagena de Indias. En realidad, eran los encargos de armamento para Ultramar, que solían llegar con dinero contante y sonante, los únicos que ya por entonces permitían a las fábricas de armas mantenerse, pagar algunos salarios y comprar todo lo necesario para seguir funcionando ${ }^{20}$. Pero incluso esa regularidad en cuanto al pago se fue perdiendo.

En 1673 se hizo un gran pedido de armas para las Indias, que incluiría un segundo aún mayor de diez mil bocas de fuego para la defensa de Perú -una solicitud tratada en la Corte a partir de agosto de ese año. Por un informe de don Diego Caballero, gobernador de Cádiz, sabemos que en existencia quedaban desde 1671 en aquella plaza 3.061 mosquetes y 2.921 arcabuces. Venían a cuento tales números, pues el primer pedido con destino a Ultramar preveía la necesidad de cubrir 1.666 mosquetes y 3.334 arcabuces. Caballero ya se veía con muy pocas armas en el almacén gaditano, sin contar con el problema cada vez más acuciante de no proveerse la fabricación de otras nuevas por falta de fondos. Y entonces arribó la comanda peruana. Don Diego Sarmiento se negó a contemplar siquiera la posibilidad de hacer frente a un encargo tan importante, pues significaba anteponer la defensa de las Indias a la de España, cuando además el Consejo de Indias pretendía que se sirviese dicho armamento por adelantado, sin pagarlo, algo insólito, cuando se les debía nada menos que 735.800 reales de plata a las fábricas de armas por material ya enviado a las Indias. En realidad, no es que desde las Indias no se pagasen las peticiones, es que, además, sus caudales se dedicaban a cubrir otras necesidades. Pero parece que Sarmiento no lo quería ver así. La conclusión a la que llegó el Consejo de Guerra fue la entrega paulatina previo pago del armamento requerido y con el dinero conseguido se pudiese seguir fabricando armas y pólvora en Aragón y Cataluña, para que aquellas fábricas no se arruinasen y no se tuviese que comprar tanto material en Italia, saliendo el dinero de España ${ }^{21}$.

Por otra petición de armas de 1675 sabemos que al Perú se enviaron finalmente cinco mil bocas de fuego, pero en aquellos meses iba a ser difícil encontrar las diez mil armas solicitadas para las Indias. En concreto se pidieron cuatro mil arcabuces de chispa con sus complementos, dos mil mosquetes de chispa asimismo con sus complementos y cuatro mil carabinas también con sus complementos. No era un tema menor contar con frascos, frasquillos, recambio de llaves, sílex u horquillas para los mosquetes. El problema era que por entonces en Cádiz sólo quedaban 3.100 mosquetes, 2.050 arcabuces y 2.870 carabinas en existencia, y esas cifras eran dudosas ya que se habían sacado armas para los bajeles que iban a Mesina, levantada en armas contra la Monarquía desde 1674, se pedían armas constantemente para Cataluña, otro frente de guerra muy activo, se habían prometido dos mil quinientas bocas de fuego para la costa de Granada o medio millar para Ayamonte. Es decir, un constante "saqueo" del almacén gaditano 22 . Y apenas si se reponían.

19 A Panamá se enviaron armas y municiones por valor de 47.014 reales de plata en 1671 que en 1673 estaban pendientes de cobro por parte del capitán general de la artillería de España. Minuta del Consejo de Indias. Madrid, 5-V-1673. AGI, Panamá, leg. 37-42.

20 Consulta del Consejo de Estado (en adelante CE). Madrid, 21-III-1672. AGS, Estado, leg. 2694; consultas del CG, Madrid, 6/15-II-1673. AGS, GA, leg. 2285.

21 Consulta del CG. Madrid, 15-V-1673. AGS, GA, leg. 2285; consulta del CG. Madrid, 28-VIII-1673. AGS, GA, leg. 2286; consulta del CE. Madrid, 30-VIII-1673. AGS, Estado, leg. 2696.

22 Consultas del CG. Madrid, 22-II-1675 y 1-IV-1675. AGS, GA, leg. 2323. 
El pedido de armas para Ultramar de 1675 fue a todas luces insuficiente, pues a inicios de 1677 informaba el secretario del Consejo de Guerra, López de Zárate, sobre una nueva solicitud de doce mil armas para, en concreto, Perú, si bien el Consejo de Indias volvía a carecer del dinero necesario, 585.000 reales, para pagarlas por haber asistido al "socorro de exércitos y armadas", aunque se reconocía que dicho Consejo entregó previamente, desde julio de 1671, 1.769 .528 reales de plata para proveer las Armadas y presidios de las Indias, y con dicha cantidad bien se podía entonces enviar aquellas armas y más adelante pagarían. Señalaba López de Zárate que las fábricas de Plasencia tenían consignados 660.000 reales al año, 550.000 para fabricar y 110.000 para los envíos, y en 1676 se gastó por valor de 978.710 reales en armas, de modo que en aquellos momentos no había dinero para cubrir esos 585.000 reales para las Indias ${ }^{23}$.

Pero algunas armas se hubieron de enviar a Perú, pues el virrey Castellar se jactó que a su llegada al gobierno de aquellas tierras en 1674 apenas si había 467 mosquetes en la armería de El Callao, de suerte que se aplicó a mejorar la situación armamentística dejando a su salida en 16781.848 mosquetes, 4.590 arcabuces y 2.180 carabinas - un total de 8.618 bocas de fuego-, sin contar con otras 1.010 armas remitidas a diversos destinos, además de 1.819 chuzos $^{24}$. Asimismo, Castellar mandó fundir en aquellos cuatro años veintisiete artillerías de bronce y dos culebrinas reales $^{25}$. Lima tenía por entonces en los fortines que la protegían un mínimo de cincuenta y siete artillerías -la fuente no explicita exactamente su número-, mientras que en El Callao disponían de cuarenta y una artillerías. Todas ellas tenían cureñas nuevas, pólvora y balas. El calibre, salvo una excepción, de aquellos cañones solía ser de entre 26 a 12 libras de bala ${ }^{26}$.

A fines de 1677 comenzó a solicitarse el envío de armas y municiones para Panamá, que fue respondido a partir de 1678, y para Tierra Firme, a donde en 1680 debían enviarse ochocientos arcabuces, cuatrocientos mosquetes y doscientas carabinas con sus complementos. Ese año, 1680, el virrey Liñán enviaba a Panamá mil armas de fuego con pólvora y balas suficientes, remitiendo también arcabuces y mosquetes a Guayaquil (cuatrocientos) y Piura (ciento cincuenta) por si recibían alguna visita de los piratas que por entonces molestaban en el Pacífico. El anterior envío, de mil arcabuces y doscientos cincuenta mosquetes, se había producido en $1666^{27}$.

En primavera de 1679, una vez finalizada la guerra de Holanda, se solicitó una remesa de armas para Paraguay vía Buenos Aires; en concreto en las fábricas de Plasencia y Tolosa se debían fundir doce artillerías de calibre 10 libras de bala junto con mil escopetas y carabinas, quinientos pares de pistolas de caballería, doscientos arcabuces, un millar de espadas y otros tantos alfanjes. Si bien el Consejo de Indias ya advertía que no podría pagar de contado aquellas armas, pues todo el dinero remi-

23 López de Zárate, secretario del CG, a Pedro A. de Aragón, presidente del CG. Madrid, 15-II-1677. AGS, GA, leg. 2399.

24 Hanke, 1979, v. V: 129-131. Además, el virrey Castellar remitió a Panamá 24.535 libras de pólvora, ciento cincuenta quintales de cuerda y seis mil balas de mosquete, todos ellos artículos difíciles de conseguir en el territorio. Hanke, 1979, v. V: 22-24, 134, 239-241 y 247-248.

25 Ibídem: 129-131.

26 Ibídem: 248-252.

27 Ibídem: 22-24, 134, 239-241 y 247-248. F. Fernández de Madrigal, secretario del CI, al presidente de la Casa de la Contratación de Sevilla. Madrid, 2-IV-1678. AGI, Panamá, leg. 231-7; Fernández de Madrigal al presidente de la Casa de la Contratación. Madrid, 29-I-1680. AGI, Panamá, leg. 231-8; Juan del Solar, secretario del CI, al presidente de la Casa de Contratación. Madrid, 4-X-1666. AGI, Panamá, leg. 231-6. 
tido en los últimos años había servido para "la defensa de estos reynos sin que haya quedado medio alguno que no esté consignado a los hombres de negocios que desde el año de 1671 a esta parte", y habían entregado al capitán general de la artillería 823.592 reales de plata para la compra de armas y municiones y otros 785.136 reales para fundir artillería. La situación debió ser tan apurada que en un momento dado se demandaron armas de fuego a los padres jesuitas del Paraná y del Uruguay, pues ese mismo año se solicitaba, al gobernador de Buenos Aires, la devolución de 473 bocas de fuego a los misioneros ${ }^{28}$.

La situación de las fábricas de armas hispanas no hizo sino empeorar, por cierto. Los diputados de la de Plasencia señalaban en 1682, por ejemplo, la falta de cobro de sus atrasos, que alcanzaban por entonces 1.688 .530 reales, y cómo una libranza que se les iba a dar de 500.000 reales tampoco salió bien. Todos los implicados ponderaban que aquello significaría la ruina de la fábrica ${ }^{29}$.

En los siguientes años se satisficieron algunos pedidos. A fines de 1682 salieron de Cádiz para los presidios de las Indias quinientos ochenta y ocho mosquetes, un millar de arcabuces y cien carabinas. En 1683 se pudo enviar a Puerto Rico un total de dos mil seiscientas balas de artillería de diversos calibres y ciento cincuenta escopetas de chispa. Y en 1684 eran medio millar de arcabuces para Paraguay $^{30}$ y otros cuatrocientos para Tucumán ${ }^{31}$ el encargo realizado. Pero desde el Consejo de Guerra se contestó al de Indias que en Cádiz no quedaban armas para enviar a parte alguna no solo por los pedidos realizados de todos los teatros de operaciones a causa de la guerra contra Francia -desde noviembre de 1683-, sino también por el mucho dinero debido a las fábricas de armas, un problema recurrente como observamos, solo que en aquella ocasión el Consejo de Guerra, indignado, señaló al monarca que se había informado del problema en consultas reiteradas del 24 de marzo, 12 de abril y 19 de julio de aquel año, sin resultado. Por ejemplo, la fábrica de Liérganes tenía consignados 233.564 reales de plata anuales de los millones de Burgos, pero entre 1682 y 1684 de los 700.692 reales a percibir apenas si habían llegado a Liérganes 86.505. Sin contar con el adeudo previo para con la fábrica cántabra de otros 231.487 reales. Así las cosas, en Liérganes "se hallan perdidos y sin esperanza de poderse desempeñar $[\ldots]$ ", protestaba el Consejo de Guerra ${ }^{32}$.

No obstante, en algunos lugares estratégicos, como Veracruz, las armas no parecieron faltar: en 1683, cuando sufrió un terrible asalto, había en almacenes nada menos que 182 mosquetes, 2.996 arcabuces y 714 carabinas, de manera que se podría haber armado un gran número de personas, muchas más que los 413 hombres de su guarnición ${ }^{33}$. También llegaron aquellos años pedidos de armas de forma regular, como los procedentes de la Real Fuerza de Santiago de Arroyo de Araya, en la

28 Consulta del CG. Madrid, 10-IV-1679. AGS, GA, leg. 2445; consulta del CI, Madrid, 15-VIII-1679. AGI, Buenos Aires, leg. 6-1.

29 Consulta del CG. Madrid, 10-VII-1682. AGS, GA, leg. 2545.

30 En 1693, quedaban trescientos arcabuces de aquel pedido. Esa cifra nos da un detalle del desgaste sufrido por las armas en el ambiente americano. Además, constaba la existencia de 189 carabinas y 437 pares de pistolas. "Informe de la contaduría". Buenos Aires, 1693. AGI, Charcas, leg. 29-57.

31 En 1666, la Audiencia de Lima, que gobernó Perú hasta el año siguiente, envió ciento cincuenta armas de fuego a Tucumán. Hanke, 1979, v. IV: 104-108 y 183.

32 José de Sepúlveda, pagador del presidio de Cádiz. Cádiz, cuentas de 10-VI-1681 a 11-XI-1683. AGS, Contadu-

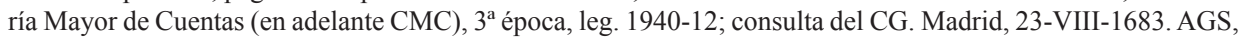
GA, leg. 2583; consulta del CG. Madrid, 11-XII-1684. AGS, GA, leg. 2613.

33 Juárez Moreno, 1972: 129-134 y 153-194. 
costa venezolana, donde en 1681 se demandaban cincuenta arcabuces, otros tantos mosquetes y cinco mil balas para rearmar las tropas ${ }^{34}$. $\mathrm{Y}$ en 1688 eran doscientos arcabuces, además de varios centenares de balas de diversos calibres para la artillería, lo solicitado, además de herramientas (marrazos, hachas y palas) ${ }^{35}$. Durante varios decenios la dotación artillera de dicho castillo sumó cuarenta piezas de bronce de 12, 20 y 25 libras de bala de calibre. Pues cuarenta artillerías se contabilizaron en 1658 y otras tantas había en $1696^{36}$.

Tras la guerra de Luxemburgo (1683-1684), en 1685 se solicitaron seiscientas armas de fuego para Panamá y Cartagena de Indias, si bien Carlos II especificó que se debían pagar de su Real Hacienda y no de la consignación de las Indias. Pero en 1687, de los dos mil mosquetes demandados por Nueva España, un millar se acabaron dejando en Gibraltar, pues se los necesitaba con mayor urgencia aún para Ceuta, Melilla y Orán, sobre todo desde que el sultán marroquí Muley Ismail estaba mucho más activo bélicamente hablando -en 1681 recuperó La Mámora (San Miguel de Ultramar) y en 1689 Larache. Al final se remitieron a las Indias mil cien mosquetes ${ }^{37}$. Y a partir de ese último año, con la terrible guerra de los Nueve Años (1689-1697) con frentes muy activos en Flandes, Milán y Cataluña, además del norte de África, la Monarquía apenas si pudo remitir armamento a las Indias. De hecho, en noviembre de 1689, cuando se solicitaron armas para Venezuela, el Consejo de Guerra exclamó: "Se hallan los almacenes de Cádiz barridos de todo género de armas y municiones, y las que está resuelto que pasen a Cádiz de las fábricas aún no se ha dado principio a ello por no haber en qué conducirlas [...]"38. Por otro lado, comenzó a haber alguna preocupación por conservar mejor el armamento disponible. Por ejemplo, el gobernador de Cuba, S. Manzaneda, comentaba en marzo de 1690 cómo el hecho de descontar las armas recibidas por su infantería de sus sueldos les daba opción, a cambio, de llevárselas a sus casas, de modo que muchos se terminaban incorporando al servicio sin ellas, o en mal estado, por no hablar de la venta de las mismas por los desertores. Así, Manzaneda propuso que las armas de la dotación de La Habana se guardasen al cuidado de los oficiales en el cuerpo de guardia principal en un recinto mandado edificar con poco gasto. Según un informe presentado aquellos días, desde 1670 se habían perdido 273 arcabuces y 37 mosquetes, ya fuese por muerte del soldado, por haber sido licenciado o por desertar y llevarse su arma ${ }^{39}$.

No hemos localizado más pedidos de armas de fuego portátiles hasta 1695, cuando la flota de la Carrera de Indias solicitaba a Cádiz la entrega de trescientos veinte mosquetes y cincuenta arcabuces. Así, cuando se demandaron armas desde Maracaibo en 1697 -el pedido incluía cincuenta quintales de plomo, ciento cincuenta escopetas, ocho pedreros de bronce de dieciséis libras de bala, o de hierro en su defecto-, se contestó que se necesitaban reponer en todos los presidios y guarniciones de las

34 Don Juan Padilla a la audiencia de Santo Domingo. Cumaná, 31-III-1681. AGI, Santo Domingo, leg. 187-90.

35 Gaspar Mateo de Acosta, gobernador de Cumaná, a Carlos II. Cumaná, 11-XII-1688. AGI, Santo Domingo, leg. 188-77.

36 Conde de Moctezuma a Carlos II. México, 5-V-1699, con copia de carta de Martín Cabeza de Vaca al virrey Moctezuma. Araya, 4-VI-1697. AGI, México, leg. 66-28.

37 Consulta del CG. Madrid, 12-III-1685. AGS, GA, leg. 2650; consulta del CG. Madrid, 2-VI-1687. AGS, GA, leg. 2725; Sebastián Martín de Velasco, tenedor de bastimentos y mayordomo de la artillería de Gibraltar.

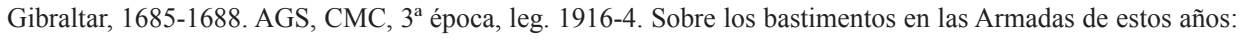
Mena, 2004.

38 Consultas del CG. Madrid, 18-23-XI-1689. AGS, GA, leg. 2792.

39 Gobernador Manzaneda a Carlos II. La Habana, 25-III-1690. AGI, Santo Domingo, leg. 110-3-37. 
Indias, pero se añadió que la falta de plomo era notoria porque las minas de Linares solo producían 1.875 quintales al año y con esa cantidad no se llega a cubrir todas las necesidades a menos que se comprase fuera ${ }^{40}$. Y no había dinero para hacerlo.

Obviamente, allá donde los enfrentamientos bélicos entraron en una fase candente aquellos años sí hubo algún intento por mejorar su parque armamentístico. Por ejemplo, en 1690, en San Juan de Puerto Rico la necesidad era, más bien, el arreglo de las armas en existencia: trescientos cincuenta mosquetes, trescientos treinta arcabuces y municiones -los 678 quintales de pólvora estaban en mal estado por humedades- por refinar, y comprar setecientas herramientas como picos, palas, hachas y azadones $^{41}$. En 1693 el gobernador de La Española solicitaba la remisión de doscientos mosquetes, otros tantos arcabuces y la misma cantidad de escopetas de chispa, así como cien quintales de pólvora ${ }^{42}$, pues con anterioridad solo se le habían mandado cien arcabuces y otros tantos mosquetes ${ }^{43}$. En 1696, Gabriel de Arredondo, gobernador de Puerto Rico, fue promocionado a gobernador de La Española, donde hizo enviar un centenar de mosquetes y otros tantos arcabuces desde su primer destino, donde habían desembarcado armas unos navíos recién llegados de la Península ${ }^{44}$. En el caso de Cartagena de Indias, capturada por el barón De Pointis en 1697, cuando se hizo cargo de su gobierno el maestre de campo general Juan Díaz Pimienta en 1699 llevó consigo un millar de armas de fuego ${ }^{45}$.

Las dificultades de los últimos años ayudan a entender cómo, a partir de 1701, con el cambio de dinastía, la armada de Francia se encargase del envío de armamento y municiones a la América hispana. En concreto, se remitieron por valor de 800.000 reales a Cartagena de Indias, Portobelo, Veracruz y La Habana para evitar su desprevención en caso de sufrir un ataque de las flotas de Inglaterra y Provincias Unidas ${ }^{46}$. Donde sorprendentemente la situación parecía más controlada era en las Filipinas, pues se había triunfado en la manufactura de arcabuces, con una capacidad anual de trescientos sesenta cuando los aborígenes habían conseguido dominar aquel arte, para alegría del gobernador Cruzat. Así, no solo se hallaban todas las plazas bien abastecidas de arcabuces y mosquetes, sino que había en depósito otros dos mil ya fabricados ${ }^{47}$.

\section{Artillería}

La cuestión de la artillería ${ }^{48}$ fundida en la Península aún estaba más ligada si cabe con el numerario procedente de las colonias americanas. Las cajas reales de Ciudad

40 Consulta del CG. Madrid, 20-V-1695. AGS, GA, leg. 2980; consulta del CG. Madrid, 4-IX-1697. AGS, GA, leg. 3045 .

41 Dos cartas del gobernador Arredondo a Carlos II. San Juan, 20-V-1690. AGI, Santo Domingo, leg. 159-120-121.

42 No toda la pólvora debía traerse de España, pues el virrey de Nueva España firmaba un asiento, al menos desde la época del conde de la Monclova, a 4 reales la libra y los primeros cuatrocientos quintales gratis. Hanke - Rodríguez, 1978, vol. V: 156-159.

43 Gobernador Pérez Caro a Carlos II. Santo Domingo, 16-18-V-1693. AGI, Santo Domingo, leg. 66-24-26.

44 Gobernador Arredondo a Carlos II. San Juan, 3-I-1697. AGI, Santo Domingo, leg. 72-52.

45 Díaz Pimienta a Carlos II. Cartagena, 5-X-1699. AGI, Santa Fe, leg. 48-37. De la Matta, 1979.

46 Copia de consulta del CE. Madrid, 4-III-1701. Archivo Histórico Nacional (en adelante AHN), Estado, leg. 6591; Consultas del CE, Madrid, 28-II-1702 y 6-IV-1702. AHN, Estado, leg. 659-1.

47 Gobernador Cruzat a Carlos II. Manila, 18-20-V-1697. AGI, Filipinas, leg. 17-3-20.

48 Gómez Pérez, 1997; Aguilar Escobar, 2008. 
de México debían destinar anualmente 246.400 reales para la fundición de artillería en Sevilla con destino a la armada del Mar Océano, pero también se enviarían diversas piezas a destinos terrestres. Por otro lado, la necesidad de hacer economías llevó ya en 1667 a la Monarquía a intentar refundir piezas inservibles, como los mil quintales de bronce depositados en Zaragoza, que deberían ser enviados por el Ebro hasta Tortosa y desde allí, en las galeras reales, a Cádiz y Sevilla, todo con un coste de 13.000 reales. El problema suscitado fue que el dinero, sencillamente, no llegó. Por otro lado, ante el fracaso de la fundición de cañones de bronce, se estaban utilizando aún piezas de artillería de hierro para la Armada, "siendo inútiles para el servicio, pues por su mucho peso no pueden ponerse del calibre que son menester para escusar el daño que recibe el navío en su retirada con que minorando el calibre es preciso que falte el alcanze". El Consejo de Guerra se lamentaba que

en toda España no haya como sucede actualmente una fábrica que este corriente habiendo habido tres por lo pasado, de lo qual considera el Consejo que para restaurar una cosa tan esencial será el medio más eficaz y el único que los treinta mil pesos de consignazión que vienen de Nueva España cada año para la fundición de Sevilla, los quales de muchos años a esta parte se han divertido a otros efectos, mande V. M. con toda precisión no se apliquen sino al referido de la fundición ${ }^{49}$.

Don Diego Sarmiento, capitán general de la artillería de España, intentó ajustar un asiento con el dinero mexicano con el fundidor alemán Enrique Havet, quien llevaba años al frente del asiento de la fábrica de artillería de bronce en Sevilla. La polémica surgió al intentarse buscar un acuerdo comercial con Suecia como suministradora de cobre, cuando Havet lo quería traer de Hungría (y el estaño de Inglaterra ${ }^{50}$. Pero disquisiciones metalíferas aparte, todo el asunto giraba en torno a los 246.400 reales de Nueva España. Y ello es así porque en 1670 Havet, que inició los trabajos fundiendo siete piezas por un valor de 80.000 reales, se negaba a entregarlas si no cobraba. Es más, amenazó con acabar abandonando aquella fundición y marcharse sin atender a más razones, pues nunca se le pagaba a tiempo y las promesas jamás se cumplían. No es de extrañar el enfado de Havet, pues en enero de 1670 se dijo que la flota de Nueva España traía el dinero apalabrado y se habían reservado 88.510 reales para él, pero es obvio que no se le pagó ${ }^{51}$. Un año más tarde, en noviembre de 1671, don Diego Sarmiento dispuso el gasto de 144.000 reales de la consignación de Nueva España, cantidad con la que por fin se pudo pagar algunos atrasos a Havet y seguir confiando en que fundiría más piezas si se le ofrecían otros 74.000 reales. Pero quedó claro que desde 1668 no se había gastado dinero alguno en dicha cuestión ${ }^{52}$.

49 Consulta del CG, Madrid, 13-I-1667. AGS, GA, leg. 2136.

50 Según Serrano Mangas, citado por Aguilar Escobar, en la fundición sevillana, entre 1650 y 1700 , “el origen del cobre fue el siguiente: cobre de Linares $0,52 \%$, de la fundición de moneda cortada 5,94\%, metal ligado 21,48\%, cobre de Hungría 28,54\%, cobre de Cuba y Caracas 41,15\%. El estaño se importaba de Inglaterra a un precio de entre 32,5 reales de plata (unos 78 reales de vellón) el quintal y 35 reales, al final del siglo XVII. En esos años la fábrica empleó un total de 32.870 quintales de cobre y 729 quintales y 99 libras de estaño". Aguilar Escobar, 2008: 76 .

51 Consultas del CG. Madrid, 7-XI-1669 y 10-XI-1670. AGS, GA, leg. 2219. Ya en 1657, Havet cobró 76.000 reales por diversas piezas fundidas con destino a Tierra Firme. Real Cédula. Madrid, 22-II-1657. AGI, Panamá, leg. 238-17.

52 Consulta del CG. Madrid. 17-XI-1671. AGS, GA, leg. 2247. 
Mientras, la fábrica de Liérganes había entregado sesenta artillerías con veinticinco disparos cada una a dos galeones que se fabricaron para la armada de Indias en Guipúzcoa. Otros cinco galeones esperaban en Cantabria para ser rearmados antes de pasar igualmente a América. Como en el caso de la fundición sevillana, el atraso se produjo al constatar que desde 1668 se estaba gastando el dinero para dichos trabajos, 154.000 reales procedentes de los millones de Burgos, a otros menesteres $^{53}$.

Tras la caída de la ciudad de Panamá en manos de Henry Morgan, la preparación de una armada bajo las órdenes del príncipe de Montesarcho, destinada a transportar tropas para su recuperación, que recalaría en Cartagena de Indias, dejó en evidencia, entre otras debilidades logísticas y estructurales, la falta de artillería en las unidades de combate hispanas, pues la Capitana, con 800 toneladas, llevaba apenas treinta y seis piezas, la Almiranta treinta y dos y entre treinta y veintiocho piezas los demás galeones y fragatas, cuando lo normal es que un navío de 500 toneladas portase de cuarenta a cincuenta piezas ${ }^{54}$.

Poco se hizo aquellos años, pues en 1672 se entregó artillería y balas para la Capitana y Almiranta de la armada del Mar Océano, pero la artillería librada era la inútil de las plazas de Cádiz, Málaga, Gibraltar, Badajoz. Como en Cádiz hubo que reponer ciento sesenta quintales de pólvora y 2.820 balas rasas de artillería, es de suponer que buena parte de ese material se embarcó para la armada de Indias. También se solicitaron aquellos meses cuatro pedreros de Cádiz para San Juan de Ulúa. El Consejo de Guerra se extrañó de que en una "isleta" como San Juan se necesitasen dichas artillerías cuando en Cádiz se habían quedado sin apenas piezas tras haber proveído de las suyas para la Almiranta y la Capitana de la armada de Indias. Pero la respuesta real fue que se fabricasen aquellas cuatro piezas en Sevilla de los restos de otras piezas que se refundían, como si aquel material fuera inagotable. Y todavía en julio de ese mismo año se informaba de haberse finalizado un galeón en Cantabria para servir en la armada de Indias, con destino a Honduras; de las treinta y dos piezas de hierro que debía portar faltaban siete por entregar, además de necesitar otro medio centenar de mosquetes para sus tripulantes, así como pólvora y balas. Y como para compensar tales deficiencias se dijo que se le iba a dotar de, al menos, veinticinco disparos por cañón. Por eso se acudió una vez más a Cádiz, donde se confesó disponer todavía de otras dieciocho piezas que se habían rescatado de algún naufragio, de particulares y de las defensas de la ciudad ${ }^{55}$.

Cuando comenzó una nueva guerra contra Francia en 1673, al año siguiente, ante la posibilidad de enfrentamientos con la armada gala en las Indias, el Consejo de Guerra volvía a insistir en que no se habían gastado para el fin primigenio para el que se los solicitaba el dinero procedente de Nueva España, es decir en la fundición de cañones de bronce, de ahí que la armada del Mar Océano no estuviese bien artillada; la realidad era que "se save que la capitana real de la Armada y los demás vageles della se tripulan de fierro, que por su mucho peso no sólo los atormenta, pero no alcançan lo que es menester, de que se sigue no llevar la fuerza conveniente para las ocasiones [...]". También se solicitaba el envío de mil quintales de pólvora para los

53 Consulta del CG, Madrid. 10-XI-1670. AGS, GA, leg. 2219.

54 Príncipe de Montesarcho a Mariana de Austria. Cádiz, 9-VII-1671; duque de Medinaceli a Mariana de Austria. Cádiz, 11-VII-1671; Junta de Armadas. Madrid, 17-VII-1671; Junta de Guerra de Indias. Madrid, 17-18-VII1671. AGS, Estado, leg. 2693.

55 Consultas del CG. Madrid, 20-VI-1672 y 17-29-VII-1672. AGS, GA, leg. 2268. 
galeones de la Carrera de Indias. Es más, tampoco se estaba pudiendo colocar en el mar una segunda armada de Barlovento, destruida en Maracaibo años atrás, porque los caudales destinados a tal empeño se habían dedicado aquellos años a la armada del Mar Océano, Cataluña y Alemania ${ }^{56}$. Todo apunta a que aquella crítica movilizó un tanto la situación de la armada de Barlovento, pues en 1675 se aseguró que se dispondría de algunos caudales, en concreto de 936.000 reales, para la misma. Una cantidad a todas luces insuficiente ${ }^{57}$. Pero es que, además, no se emplearon en tal menester. Y lo sabemos porque en 1676 hubo duras quejas al haberse perdido el situado de Santo Domingo, 372.000 reales de plata, por apresar los ingleses el navío de don Bernardo de Espejo que lo transportaba. Las críticas apuntaron sin duda como una causa principal de aquel desastre a la ausencia de una armada de vigilancia en aquellas aguas ${ }^{58}$.

Mientras, en la fábrica de Liérganes continuaban librando piezas de artillería para la armada de la Carrera de Indias, doscientas cuarenta y tres en 1676. El caso es que el capitán general de la artillería de España, marqués de Cerralbo, recibió órdenes en noviembre de 1676 y enero de 1677 de que en Santander se entregasen otras ciento treinta y una piezas, y en junio de 1677 se llevaron otras dieciséis artillerías de Santander a Cádiz en los galeones que debían pasar a América. Y a lo largo de 1677 el Consejo de Guerra trató acerca del armamento de la flota que debía navegar hacia Nueva España en 1678, pues a la Capitana y a la Almiranta les faltaban nada menos que ochenta piezas. En octubre de 1677 se entregaron en Cádiz ciento veinticuatro piezas, de las cuales se cedieron noventa y cuatro para la armada de la Carrera. Aquellas circunstancias se entienden mejor al saber que dicha Armada había cedido a su vez ciento ochenta piezas de artillería de bronce para rearmar la armada del Mar Océano que actuaba en la guerra de Mesina en 1676 y no se le habían devuelto. Ahondando en la cuestión se dijo, pero ya en enero de 1679, que los siete galeones y dos pataches de la armada de la Carrera de Indias necesitaban trescientas veinte piezas artilleras y dos galeones de la flota de Nueva España otras ochenta piezas, pero en Sevilla solo quedaban disponibles doscientas setenta y una artillerías, de modo que faltaban otras ciento veintinueve para cubrir aquella necesidad. Eso sí, si la Armada que había luchado en Italia devolvía las piezas prestadas, aunque el Consejo de Indias se conformaba con ciento cincuenta y cinco, el tema estaba solucionado. Se añadía que las piezas necesitadas eran de 25 y 18 libras de bala de calibre. No obstante, el Consejo de Guerra pasó a la ofensiva argumentando en 1680 que "la Armada [del Mar Océano] se halla [h]oy más necessitada de artillería de bronce que por lo pasado, pues por la pérdida de los vageles que ha padecido en Ytalia assí por los accidentes de la mar como por incendio en los reenquentros que ha tenido con las armas de Francia se [h]an perdido muchas pieças de bronze [...]”, tanto era así que la Monarquía se vio abocada a comprar artillería de hierro sueca para armar los buques en construcción. Y añadían que si desde 1675 se hubiesen hecho efectivos los 246.400 reales que había consignados para fabricar artillería las cosas serían muy diferentes, pero no había sido así. Y el saqueo continuó, pues todavía en octubre de

\footnotetext{
56 La cita en consulta del CG. Madrid, 7-V-1674. AGS, GA, leg. 2301; Consultas del CE. Madrid, 7-23-II-1674. AGS, Estado, leg. 2698.

57 Consulta del CE. Madrid, 28-III-1675. AGS, Estado, leg. 2700.

58 Consultas del CE. Madrid, 8-IV-1676, 7-VII-1676 y 9-X-1676. AGS, Estado, leg. 2702.
} 
1680 el Consejo de Guerra trató sobre la petición de sesenta cañones de la armada de la Carrera para armar las nuevas unidades que se construían ${ }^{59}$.

En realidad, este tipo de comportamientos se acabaron por institucionalizar: se utilizaba el dinero de determinadas consignaciones para otros menesteres distintos a los originales; se empleaba la artillería, demás armas y municiones, por no hablar de tripulantes y tropas, para cubrir las necesidades perentorias de determinada escuadra o armada, pero dejando casi desarmada a otras, que debían esperar a que unas fábricas siempre cortas de caudales pudiesen abastecerlas del armamento necesario. Incluso, como se ha visto, durante años se desviaron los caudales apalabrados para volver a poner en el mar la armada de Barlovento a otros servicios más acuciantes. $\mathrm{Y}$ con los años dichas actuaciones no cambiaron.

A todas luces, la factoría de Liérganes sustituyó en parte los encargos que otrora recibiera Enrique Havet en Sevilla, si bien este siguió trabajando a tenor de algunos pagos efectuados aquellos años. Se solicitaron pagos para Havet en $1677-21.544$ reales se demandaron a la Casa de la Contratación en mayo de dicho año; en noviembre, mediante una Real Cédula, se le cedían a Havet los caudales que produjesen los servicios voluntarios solicitados a los fabricantes y mareantes que componían los buques de las flotas de Tierra Firme y Nueva España- y en 1678 se le liquidaron 200.000 reales por cuenta de algunos encargos ya efectuados y otros nuevos, como dieciocho esmeriles con destino a Paraguay, así como otras piezas para rearmar la flota de la Carrera. En 1679 Havet recibió unos magros 3.123 reales de plata por el valor del metal a utilizar en la fundición de los esmeriles para Paraguay y la promesa de recibir alguna cantidad por cuenta de la consignación de la artillería que se enviaba desde Nueva España. Es decir, las promesas de siempre ${ }^{60}$. Ahora bien, la situación de la fundición de Liérganes no es que fuera mucho mejor, pues un encargo de 1681 para dotar de ochenta artillerías los dos galeones que fabricaba don Juan de Olaeta en aquellos momentos reveló que el Consejo de Indias debía hasta la fecha 638.000 reales por encargos ya entregados ${ }^{61}$.

En otras ocasiones, algunos particulares podían proporcionar armamento de manera puntual. Fue el caso del gaditano Juan de San Miguel, quien había cobrado en 1677 el coste de los treinta pedreros proporcionados en su momento para la fortificación del castillo que protegía el río Chagre. En 1680, todavía se preguntaba el Consejo de Indias sobre las diligencias efectuadas acerca del envío a Tierra Firme de dos culebrinas enteras y cinco medias culebrinas, que había solicitado el presidente de la Audiencia de Panamá. Y en 1681 se solicitaban a la fundición sevillana veinticuatro pedreros, con tres cámaras cada uno, se especificó, para remitirlos a los castillos de San Felipe y Santiago de Portobelo, si bien en septiembre de 1682 se hubo de repetir la orden. Ese mismo año también se trató sobre la orden de fabricar seis culebrinas

59 Consulta del CG. Madrid, 27-XI-1676. AGS, GA, leg. 2377; consulta del CG. Madrid, 12-XI-1677. AGS, GA, leg. 2376; consulta de la Junta de Armadas. Madrid, 4-I-1679. AGS, GA, leg. 3641; consulta del CG. Madrid, 8-IV-1680. AGS, GA, leg. 2477; consulta del CG. Madrid, 9-X-1680. AGS, GA, leg. 3657. El trasvase de artillerías de una armada a otra venía de lejos, pues ya en 1665, por solo tratar del reinado de Carlos II, por una Real Cédula se ordenaba a la Casa de la Contratación de Sevilla que cuarenta y cuatro piezas de la armada de Indias pasasen a la del Mar Océano. Real Cédula. Madrid, 29-III-1665. AGI, Indiferente, leg. 439-22.

60 Consulta del CI. Madrid, 18-V-1677. AGI, Indiferente, leg. 441-28; Real Cédula. Madrid, 6-XI-1677. AGI, Indiferente, leg. 441-29; consultas del CI. Madrid, 26-IX-1679, 24-X-1679 y 9-21-XI-1679. AGI, Buenos Aires, leg. 6-1; consulta del CI. Madrid, 15-VIII-1678. AGI, Buenos Aires, leg. 3-9; Francico Fernández de Madrigal, secretario del CI, a la Casa de la Contratación. Madrid, 26-XII-1679. AGI, Indiferente, leg. 442-30.

${ }_{61}$ Consultas del CG, Madrid, 5-XI-1681 y 5-XII-1681. AGS, GA, leg. 2512. 
de a 25 libras de bala de calibre para Buenos Aires, en concreto para guarnecer los dos baluartes del castillo que se había de edificar en aquella plaza, además de cuatro medias culebrinas para el puerto de Matanzas; por otro lado, en Sevilla la fundición también tenía pedidos de la armada del Mar Océano: veintiséis cañones de a 25 libras de bala de calibre, otras tantas piezas de a 16 libras de bala y veinte artillerías más de 6 libras de bala, cuando el Consejo de Guerra hubo de recordar cómo "en aquella fundición solo se pueden fundir cada año treinta y seis pieças de a veinticinco libras por su mucho pesso, que para esto se neçessita de metales que no se pueden traher sin dinero de contado". La respuesta real demandaba el envío con prioridad a las Indias de las piezas solicitadas, primero a Matanzas y luego a Buenos Aires, presumiblemente porque aún no estaban acabados los baluartes ${ }^{62}$.

Pero no se podían atender todas las peticiones que llegaban, ni mucho menos. Entre 1677 y 1679 arribaron peticiones de artillería de bronce, más resistente al deterioro en los climas tropicales que la de hierro, de isla Margarita, La Guaira o de La Habana, donde se solicitaron de sesenta a ochenta piezas de 6 libras de bala de calibre, pero desde la Casa de Contratación se hubo de disculpar su envío a causa "del mucho tiempo que es menester para fundirla, mayormente cuando se necesita para la tripulación de los galeones [...]". En marzo de 1680 todavía no se pudo dar una respuesta positiva a tales demandas, y a otras llegadas de Caracas, Florida y Campeche, porque "para ello son menester 1.812 quintales de metal y se tardarían en fabricar treinta meses" $"$.

Fue un ataque contra Centroamérica, el referido de Henry Morgan de 1670 contra Panamá, el causante de que el virrey de Nueva España, marqués de Mancera, ordenase limpiar la artillería del castillo de Acapulco -treinta y cinco piezas de bronce de gran calidad- y colocarle cureñas nuevas, pues "toda yacía no solo desmontada, sino cubierta de arena" ${ }^{64}$. Por un informe de 1683 sabemos que la artillería de dos baluartes del castillo de San Juan de Ulúa estaba en mal estado de conservación, así como los herrajes de sus cureñas, mientras que solo la artillería de la plaza de armas parecía estar en buen estado, pero consistía apenas en dos cañones de bronce. Un testigo en el juicio de residencia del virrey, conde de Paredes, achacaba todos los males de la deficiente defensa del litoral de la Nueva España a la falta de pólvora de calidad, una circunstancia que, en un momento dado, inhabilitaba la respuesta ofensiva o defensiva que pudiera ofrecerse desde muros y bajeles. Los resultados de la imprevisión fueron trágicos, pues a la captura de Veracruz en 1683 seguiría la de Campeche dos años más tarde por idénticos protagonistas ${ }^{65}$. A posteriori se harían planes, como levantar nuevas defensas y artillarlas convenientemente en los casos de Veracruz y Campeche, esta última con ochenta piezas ${ }^{66}$.

En 1685 no llegó con la flota de Nueva España caudal alguno para la fundición de artillería de Sevilla, de manera que el asentista de la misma ${ }^{67}$ había comunicado que

62 Francisco Fernández de Madrigal al presidente y oficiales de la Casa de la Contratación de Sevilla. Madrid, 23-II-1677. AGI, Panamá, leg. 231-7; Fernández de Madrigal a la Casa de la Contratación de Sevilla. Madrid, 15-XI-1680, 29-IV-1681 y 24-IX-1682. AGI, Panamá, leg. 231-8; consulta del CG. Madrid, 11-V-1682. AGS, GA, leg. 2544. Zapatero, 1985

${ }_{63}$ Citas en Aguilar Escobar, 2008: 34.

64 Hanke - Rodríguez, 1978, v. V: 34-40

65 Juárez Moreno, 1972: 116-122, 279-280 y 331-366.

66 Torres Ramírez, 1981: 95-102.

${ }_{67}$ Al morir Enrique Havet, su hijo Enrique Bernardo Havet se quiso hacer cargo por diez años del asiento de la fundición de la artillería de bronce de Sevilla, siempre que del primer dinero que llegase de América se le 
por ello y porque ya no cobraría lo que se le adeudaba alzaba la mano de aquel negocio. En el Consejo de Guerra se lamentaron acerca de qué iba a pasar con el pago de las seis culebrinas reales que se habían fundido para Maracaibo aquellos meses. El caso es que en primavera de 1686 se habían fundido otras cuatro medias culebrinas y seis sacres para las Indias, es decir un encargo muy reducido. De ahí que hubiese que reaprovechar todo el material posible: por ejemplo, ese mismo año de 1686 se entregaban a la Avería las veintitrés piezas de bronce que se habían podido recuperar de un galeón hundido en las costas de Portobelo ${ }^{68}$.

En la segunda mitad de la década de 1680 la Monarquía continuó encargándole artillería a las fundiciones cántabras, Liérganes y La Cavada, en una proporción importante, pero siguió sin pagar mejor. En un informe de 1689 se aseguraba que se habían librado para Indias solo en el año precedente ciento cuarenta y dos piezas, con medio centenar de balas para cada una, es decir 7.100 balas, con un valor de 260.000 reales. El problema era que desde 1686 solo se habían pagado de la consignación de Nueva España 428.823 reales, incluidos los últimos 64.000 reales librados, a los asentistas de las fundiciones, cuando informaba el veedor general que con dicha cantidad "no solo no se halla cubierto el alcançe, pero ni aun con esta cantidad la mitad de lo que después se ha fabricado, de que se orixina no haver podido hacer fundición este año [1689]". Claramente, el Consejo de Guerra daba la voz de alarma, pues incluso los técnicos alemanes y flamencos que trabajaban allá se estaban marchando a otros lugares en vista de la falta de cobro, máxime cuando ya hacía también muchos años que "está mui atrasada la fundición de la de bronce de Sevilla por no asistirse con los treinta mil y ochocientos pesos que tiene de consignación en México"69

En vista de esta doble problemática que tanto afectaba a la fundición sevillana como a la cántabra, no deja de ser un tanto patética la "picaresca" a la que la propia administración se veía obligada a incurrir. En 1688, en los astilleros de Colindres (Cantabria), se tenía que armar la Capitana de la armada del Océano con artillería de bronce, y la propia Junta de Armadas señaló que se solicitasen las artillerías a la fundición de Sevilla como si fueran para la armada de Indias, cuyos gastos se pagaban del impuesto de la avería para "conseguirla a precio más acomodado". Además, para ayudar en su fabricación se debería recoger toda la artillería de bronce de las plazas del norte de África y de Cartagena que estuviese en mal estado y transportarla a Cádiz y de allí a Sevilla ${ }^{70}$.

La demanda de pólvora fue muy recurrente, pero no toda debía traerse de España, pues el virrey de Nueva España firmaba un asiento, al menos desde la época del conde de la Monclova en la década de 1680, a cuatro reales la libra (y los primeros cuatrocientos quintales gratis $)^{71}$. Por cierto que al asentista de la pólvora, don Juan de Alvarado, se le debían a la altura de 1699 nada menos que 188.800 reales $^{72}$. Y

pagasen los 61.450 reales de plata que alcanzó su padre en la última cuenta que pasó con la Real Hacienda. Havet hijo se comprometía a seguir cobrando 38 reales y medio de vellón por quintal de artillería de bronce que fabricase. Consulta del CG. Madrid, 2-VIII-1683. AGS, GA, leg. 2583. Solo en 1689 cobró Havet hijo 116.058 reales de plata de las deudas contraídas por la Monarquía con su padre. Aguilar Escobar, 2008: 81.

68 Consulta del CG. Madrid, 29-VIII-1685. AGS, GA, leg. 2685; consulta del CG. Madrid, 17-V-1686. AGS, GA, leg. 2687; carta de Francisco de Amolaz, secretario del CI, a Pedro de Oreitia, presidente de la Casa de la Contratación de Sevilla. Madrid, 12-XI-1686. AGI, Panamá, leg. 231-9.

69 Consulta del CG, Madrid, 6-IV-1689. AGS, GA, leg. 2791.

70 Consulta de la Junta de Armadas, Madrid, 10-II-1688. AGS, GA, leg. 3762.

71 Hanke - Rodríguez, 1978, v. V: 156-159.

72 Conde de Moctezuma a Carlos II. México, 7-IV-1699. AGI, México, leg. 66-11. 
dependía del funcionamiento del asiento que se pudiese servir con mayor o menor fluidez a determinados destinos: el gobernador de San Agustín de la Florida, Torres Ayala, se quejaba en 1697 de no disponer de apenas pólvora, pues en cada envío apenas le remitían veinticinco quintales de Nueva España, salvo en mayo de 1694 cuando recibió de golpe un envío de doscientos quintales, pero desde entonces nada más $^{73}$. Y no era un caso excepcional ${ }^{74}$.

En el caso de Perú, al menos, en parte las carencias en el envío de cañones se hubieron de suplir con producción propia aquellos años. Durante el gobierno de Melchor de Navarra y Rocafull, duque de la Palata (1681-1689), la capacidad artillera de los presidios de El Callao, Valdivia, Valparaíso y la Armada era de trescientas diez piezas, quien hubo de mandar fundir cuarenta y dos piezas y cincuenta y tres pequeños cañones llamados bayartes ${ }^{75}$, si bien sirvieron para compensar las pérdidas en el hundimiento del San José en 1685. El virrey mantuvo once piezas artilleras en Arica y cuatro en Pisco, si bien tuvo deseos de enviarlas todas a El Callao, mientras remitió ocho cañones a Panamá a defender el puerto de Perico ${ }^{76}$. En los años del virreinato del duque de la Monclova, que se prolongó de 1689 a 1705, la armada del Mar del Sur disponía de ciento cuarenta y cuatro cañones, pues entre 1691 y 1694 se construyeron dos nuevos galeones - de 845 y 700 toneladas-, que portaban cuarenta y treinta y seis cañones ${ }^{77}$.

Como en el caso de las armas de fuego portátiles, cabe achacar a los frentes de guerra abiertos en Europa y el norte de África en la década de 1690 la principal razón por la que se redujo de manera notoria el envío de artillería a las Indias desde la Península. Cuando en junio de 1690 el gobernador de Santiago de Cuba, don Juan de Villalobos, solicitó de manera perentoria mil balas de artillería -quinientas de los calibres 10, 8, 6 y 5 libras de bala, y otras quinientas de los calibres del 1 al $3-$, además de cien quintales de cuerda, "pues la que [h]ay a 26 años que se embió y está de mala calidad", de hecho el Consejo de Indias se dirigió al capitán general de la artillería de España para proveer todo ese material en 1691, pero su respuesta fue "no haber ninguno de ellos en los almacenes de Cádiz" portantes, como Buenos Aires, presentaban ciertos niveles de armamento, aunque las fuentes no siempre informan del origen del mismo. Por ejemplo, en 1693 el gobernador Agustín de Robles informaba sobre el armamento disponible: el parque artillero estaba compuesto por sesenta piezas -cuarenta y nueve de hierro y el resto de bronce-, así como nueve pedreros, pero se hallaban "pasados y quebrados". Balas de artillería había en existencia 10.114, pero con el detalle significativo que 2.487 no podían usarse allá a causa de no coincidir con los calibres de las piezas en servicio

73 Torres y Ayala a Carlos II. San Agustín, 4-II-1697. AGI, Santo Domingo, leg. 228-30.

${ }^{74}$ El gobernador de San Cristóbal de La Habana recibió así doscientos quintales de pólvora, y cien de plomo, en 1663. y 50.000 pesos para las defensas del puerto de San Cristóbal de La Habana en 1663. Poco después, a La Habana se enviaron otros seiscientos quintales de pólvora, pero no parece que hubiese un nuevo envío hasta varios años más tarde (se remitieron otros cien quintales en 1685). Hanke - Rodríguez, 1977, v. IV: 186-188.

75 Se trataba del modelo de cañón de pequeño calibre y pensado para la guerra en la montaña catalana de don Juan Bayarte, gobernador de Menorca e Ibiza. El duque de la Palata explicaba que Bayarte en persona le explicó el manejo de su invención en la Corte. Hanke, 1980, v. VI: 254-255. Sobre Bayarte, véase Espino, 2009.

76 Pérez Mallaína - Torres, 1987: 105-108; Hanke, 1980, v. VI: 55.

77 Pérez Mallaína - Torres, 1987: 77 y 91-92; Bradley, 1992: 116-118.

78 Gobernador de Santiago de Cuba a Carlos II. Santiago, 26-VI-1690 y "Resumen de dos cartas del gobernador de [Santiago] de Cuba [...]", Junta de Guerra de Indias. Madrid, s. f., pero de 1690 o 1691. AGI, Santo Domingo, leg. 111-2-55. 
en dicha plaza. Cabe decir que la pólvora almacenada había aumentado hasta los 457 quintales desde 169179.

Solo en 1698 se pagó a Enrique Bernardo Havet 31.832 reales de plata por cuatro esmeriles para la isla de Trinidad y un cañón para la flota del general Ignacio del Barrio, cuando las armas se entregaron ya en $1695^{80}$. En 1697 se solicitaron artillerías desde Maracaibo y desde el Consejo de Guerra se contestó que se necesitaban reponer en todos los presidios y guarniciones de las Indias. El gobernador de Maracaibo pedía, por ejemplo, medio centenar de quintales de plomo y ciento cincuenta escopetas, además de ocho pedreros de bronce de 16 libras de bala, o de hierro en su defecto ${ }^{81}$, lo que tampoco era una demanda desaforada.

Aunque, desde luego, fue la caída de Cartagena de Indias en 1697, así como la necesidad de expulsar de Panamá a la compañía escocesa, establecida allá efímeramente a partir de 1698-1699, las circunstancias que, sin duda, movilizaron el envío de nuevos medios de guerra a las Indias. Ya en junio de 1698 se decidió remitir artillería de bronce a Cartagena de Indias, pero ante la falta de material una solución barajada fue que se enviasen veinticuatro piezas de bronce de 10 libras de bala de calibre de la fábrica de Liérganes, porque de otro calibre no la había ${ }^{82}$. Es decir, una decisión que no significaba apenas una mejora defensiva real. Y un año más tarde, en 1699, se trataba en el Consejo de Guerra sobre las muchas peticiones recibidas para Panamá y Cartagena, entre otras una de mil quintales de pólvora, que se debían comprar por no contar con dicha cantidad almacenada en parte alguna; los dos morteros solicitados no se sabía de dónde podrían sacarse, de modo que había que enviar medios para fundirlos en Sevilla -también se pidieron seis culebrinas de bronce, pero se especificó una vez más que la consignación de Nueva España para la fundición de artillería no llegaba-; en cuanto a la cuerda, se enviaron doscientos quintales a Cádiz y el vizconde de la Armería, el asentista navarro don José Aldaz, aseguraba que podría poner en los galeones sitos en el puerto de Pasajes treinta mil granadas de mano y dos mil granadas reales, así como cuatro morteros pequeños que estaban en Pamplona, con la obligación de reemplazarlos en menos de seis meses. Un servicio por el que solicitaba que su hermano, Francisco de Ulzurrún, fuese nombrado oidor o alcalde de la corte de Navarra, una plaza ya ofrecida en 1696 y que no había tenido efecto. El Consejo de Guerra estaba de acuerdo en que se enviasen aquellas armas mediante los galeones atracados en Cantabria y recogiendo material en Cádiz, pero que de los morteros que se fundiesen en Sevilla para Cartagena de Indias, dos se remitirían a Darién, desde donde siempre se pueden volver a enviar a Cartagena. Y se debía buscar de manera urgente medios para la fabricación de la pólvora ${ }^{83}$.

79 "Informe de la contaduría". Buenos Aires, 1693. AGI, Charcas, leg. 29-57.

80 Aguilar Escobar, 2008: 82. Según este autor, y Serrano Mangas, la familia Havet fundió entre 1650 y 1700 un total de 726 piezas de diversos calibres, es decir una media de 14 piezas y media por año. Una ratio bajísima que demuestra la decadencia a la que había llegado la Monarquía, pues se trataba de la principal factoría de cañones de bronce. Los tipos de armas fueron los siguientes: 19,28\% de cañones de 10 libras de bala de calibre; 17,63\% de 16 libras; 5,65\% de 18 libras; 5,2\% de 24 libras; 4,41\% de 25 libras; y un 16,12\% de calibre desconocido; morteros y pedreros un $11,30 \%$. Ahora bien, si la producción fue importante en la década de 1660, más tarde se fue hundiendo paulatinamente, y apenas sesenta y tres piezas se enviaron a las plazas de las Indias, mientras que doscientas veintinueve fueron a parar a las flotas y armadas (y trece a las galeras). Ibídem, pp. 83-86.

81 Consulta del CG. Madrid, 4-IX-1697. AGS, GA, leg. 3045.

82 Consultas del CG. Madrid, 18-20-VI-1698. AGS, GA, leg. 3073.

83 Consultas del CG. Madrid, 15-19-VI-1699 y 1-VII-1699. AGS, GA, leg. 3100. 
No obstante, fue la amenaza escocesa sobre el Darién desde 1698-1699, magnificada en todo caso por ciertos historiadores ${ }^{84}$, la que preocupó a las autoridades hispanas en el cambio de centuria. El conde de Canillas desde Portobelo y el gobernador de Cartagena, Juan Díaz Pimienta, organizaron una flota de once velas y un total de mil quinientos efectivos para desalojar a los escoceses. Mientras, desde la Península, debía partir una escuadra compuesta por diez navíos de guerra y varios pataches, siendo comandada por el almirante Pedro Fernández de Navarrete ${ }^{85}$, quien viajaría con dos morteros con mil bombas, mil quintales de pólvora, doscientos quintales de cuerda, quinientas escopetas de chispa y doscientos chuzos, junto con veinte mil granadas $^{86}$. A inicios de marzo de 1700, la expedición de Canillas y Díaz Pimienta alcanzó el Darién y el 11 de abril los colonos escoceses se rendían; el 22 de abril entraba en el fuerte de San Andrés Díaz Pimienta. Interpelado, el virrey Monclova vio muy difícil cumplir el encargo real de remitir entre ocho y una docena de piezas artilleras de bronce, de entre 12 y 24 libras de bala de calibre, al nuevo emplazamiento militar a causa, una vez más, de las dificultades del transporte por el istmo panameño, pues la artillería dejada por los escoceses era de hierro ${ }^{87}$.

En otros casos, como el de Filipinas, se intentó fundir artillería. De hecho, el gobernador Curucealegui gastó hasta 168712.000 reales en la casa de la fundición, pero el terremoto que asoló la ciudad en 1688 acabó con buena parte de las obras del edificio, cuya reedificación se presupuestó en 17.408 reales $^{88}$. Pero el verdadero problema iba a ser la falta de un maestro fundidor competente en Manila, pues al que había se le suspendió el empleo por fallarle todas las piezas que fundía. Carlos II era consciente de la dificultad de enviar artillería a Filipinas por lo que el ideal era fundirlos allá mismo. De hecho, en 1700 el capitán general de la artillería de España, marqués de Leganés, solicitaba al asentista de la fundición de artillería de Sevilla, Enrique Havet, un par de oficiales competentes para trasladarlos a Manila. La respuesta de Havet fue comentar cómo él mismo se encontraba sin apenas personal, habiendo muerto uno de sus oficiales, y cuando solicitó a Flandes un sustituto no quiso ir ni a Sevilla, cuanto menos a Manila ${ }^{89}$.

Es más, al hundirse el galeón Santo Cristo de Burgos y perderse sus treinta y cuatro piezas de bronce, se recurrió a sacarlas de los muros de Manila para dotar lo antes posible con artillería al galeón sustituto. El gobernador Zabálburu apenas pudo ordenar la fundición de cuatro artillerías de hierro de 12 libras de bala de calibre y otras doce piezas de bronce, pero de solo 8 libras de bala de calibre. Fue aquella una muy pobre contribución a la mejora del parque artillero de las fortificaciones filipinas, pues una certificación acreditaba que en todas ellas faltaban nada menos que ciento cuarenta y seis piezas para tener su defensa asegurada: en los bastiones de Manila se necesitaban ochenta y cuatro piezas para coronarlos con garantías, treinta y una piezas en el castillo de Santiago, así como otras dieciocho en el castillo de

\footnotetext{
Storrs, 2000 .

Consulado de Sevilla a Carlos II. Sevilla, 21-VIII-1699. AGI, Estado, leg. 74-65.

Monclova a Carlos II, Lima, 26-VIII-1700; ref. en Moreyra - Céspedes del Castillo, III, 1955: 93-100.

Monclova a Carlos II, Lima, 19-XI-1700; ref. en Moreyra - Céspedes del Castillo, 1955, III: 125-131.

88 Gobernador Curucelaegui a Carlos II. Manila, 25-XII-1687. AGI, Filipinas, leg. 13-2; gobernador interino Abe1la Fuertes a Carlos II, Manila, 28-V-1689. AGI, Filipinas, leg. 25-7.

${ }_{89}$ Gobernador Cruzat a Carlos II. Manila, 18-20-V-1697 y Leganés al secretario del CI, López de Caro. Madrid, 14-III-1700. AGI, Filipinas, leg. 17-3-20.
} 
San Felipe de Cavite y otras trece en la plataforma y muelle ${ }^{90}$. Y con esa lamentable noticia se cerraba el reinado de Carlos II en aquellas latitudes.

\section{Conclusiones}

Es obvio que las dificultades económicas de una monarquía en plena decadencia afectaron sobremanera a una problemática tan sensible ante la falta de numerario como lo era la defensa en las últimas décadas del siglo XVII. Si bien la Monarquía Hispánica pudo gastar mucho dinero en la construcción y mantenimiento de las fortificaciones que defendían sus territorios en Ultramar, e hizo todo lo posible por tener bien guarnecidas dichas plazas, una cuestión en la que tampoco salió bien parada, casi todo ese esfuerzo podía quedar en nada, o apenas nada, si las tropas carecían de armas y municiones, y si los muros que tanto esfuerzo había costado edificar y mantener en buen estado de conservación se encontraban sin apenas artillería de calidad. De ahí que una de las mayores preocupaciones de los hombres del rey fuese el envío oportuno de todos los suministros militares que se les solicitaban desde las Indias, sin obviar el propio esfuerzo manufacturero y distribuidor realizado en los propios virreinatos.

Como se ha comprobado, la falta de numerario impidió a menudo un correcto funcionamiento de las fábricas de armas en Europa, actuando todas ellas bajo un régimen de asiento. En realidad, sin dinero poco o nada daba que fuese la administración o particulares quienes se encargasen de la fabricación de armamento. Además, los muchos frentes a cubrir en el transcurso de un reinado marcado por las guerras contra Francia (1667-1668, 1673-1678, 1683-1684, 1689-1697), hizo que las Indias tuviesen que competir con las demandas de armas llegadas desde Milán, Flandes, Cataluña o las plazas del Norte de África, pero también de Galicia, Guipúzcoa, Navarra, Aragón, Valencia o las Baleares. En definitiva, se intentó enviar en cada momento el volumen de arcabuces, mosquetes y sus complementos que se pudo a cada destino, nunca el requerido, pues hemos mencionado suficientes pruebas acerca de una cierta tardanza a la hora de servir los pedidos. Y, sobre todo, se ha demostrado cómo a menudo se produjo el trasvase de armas y municiones de una armada a otra, de una escuadra a otra, de un territorio al vecino. Lo más lamentable es que, habitualmente, se prefirió la remesa de armas a ejércitos que luchaban en Europa, sobre todo el de Flandes, pero también a Cataluña y el norte de África en la década de 1690, cuando el poco dinero que llegaba con regularidad para tales menesteres, y que, por cierto, se solía desviar a otros, arribaba por entonces desde las Indias.

Una de las pocas salidas que se barajaron fue la fabricación in situ de material de guerra, tanto en la misma América como en Filipinas, que se distribuiría posteriormente dentro del ámbito virreinal más cercano, e incluso se llegó a firmar un nuevo asiento en Nueva España para la pólvora en la década de 1680. Si bien en Perú se fabricó artillería en una cierta cantidad, y en Filipinas triunfó la manufactura autóctona de armas de fuego de mano, lo cierto es que esas iniciativas nunca parecieron ser suficientes. Por otro lado, en ciertas ocasiones se hizo referencia a los precios del material de guerra indiano en comparación con la manufactura europea, siendo aquellos superiores, cuando se buscaba una centralización que asegurase cuantías 
inferiores, pero que fracasaban en cuanto entraba en liza la debilidad de las estructuras productivas. Los distintos asentistas de armas, en realidad, apenas si lograron sobrevivir ni siquiera con la demanda americana.

En definitiva, pocas veces se sirvieron los pedidos solicitados originalmente teniendo en cuenta las cantidades y calibres requeridos. Los tiempos de espera fueron notorios y, lo peor, las calidades deseadas, en especial artillería de bronce, no siempre estuvo disponible para las Indias. Lo usual, como se ha señalado, fue saquear armamento de un lugar, o de una escuadra, para paliar la severa falta del mismo en otro en un momento determinado. Una solución que no era tal y que solo demuestra, de hecho, la profunda crisis productiva, además de en otros niveles, en los que estaba sumida la Monarquía Hispánica a la altura del reinado de Carlos II.

\section{Referencias bibliográficas}

Aguilar Escobar, Antonio. "La Real Fundición de Sevilla (1717-1808)". Tesis doctoral, UNED, 2008.

Alcalá-Zamora, José. Historia de una empresa siderúrgica española: Los Altos Hornos de Liérganes y la Cavada, 1622-1834. Santander: Institución Cultural de Cantabria-Centro de Estudios Montañeses, 1974.

Ayats, Alain. Louis XIV et les Pyrénées catalanes de 1659 à 1681. Perpiñán: Trabucaire, 2002.

Bradley, Peter T. "The Defence of Peru, 1648-1700". Jahrbuch für Geschichte Lateinamerikas, vol. 29 (1992), 91-120.

Cénat, Jean-Philippe. Le roi stratège. Louis XIV et la direction de la guerre, 1661-1715. Rennes: PUR, 2010.

De la Matta, Enrique. El asalto de Pointis a Cartagena de Indias. Sevilla: CSIC, 1979.

Echevarría, Miguel A. "El ejército de Flandes en la etapa final del régimen español (16591713)". En Guerra y Sociedad en la Monarquía Hispánica: política, estrategia y cultura en la Europa Moderna (1500-1700), vol. I., editado por García Hernán, Enrique - Maffi, Davide. Madrid: CSIC - Mapfre - ed. Laberinto, 2006, 553-578.

Espino, Antonio. Juan Bayarte Calasanz y Ávalos (1622-1689), Un governador de la Ribagorça a la Mediterrània de Carles II. Benabarre: CER, 2009.

Gómez Pérez, Carmen. "El problema logístico y la operatividad de la artillería en América". Militaria. Revista de Cultura Militar, vol. 10 (1997), 43-55.

Hanke, Lewis - Rodríguez, Carlos. Los virreyes españoles en América durante el gobierno de la casa de Austria: México, vols. IV-V. Madrid: Atlas, 1977-1978.

Hanke, Lewis (ed.). Perú. Los virreyes españoles en América durante el gobierno de la Casa de Austria, vols. IV-V-VI. Madrid: Atlas, 1979-1980.

Juárez Moreno, Juan. Piratas y corsarios en Veracruz y Campeche. Sevilla: CSIC, 1972.

Lynn, John. Giant of the Grand Siècle. The French Army, 1610-1715. Cambridge: CUP, 1998.

Mena, Carmen, "Nuevos datos sobre bastimentos y envases en armadas y flotas de la Carrera". Revista de Indias, vol. 64, nº 231 (2004), 447-484.

Mesa, María del Pilar. "Sicilia en la estrategia defensiva del Mediterráneo (1665-1675)". En Tiempo de cambios. Guerra, diplomacia y política internacional de la Monarquía Hispánica (1648-1700), editado por Sanz Camañes, Porfirio. San Sebastián de los Reyes: Actas, 2012, 387-414. 
Moreyra, Manuel - Céspedes del Castillo, Guillermo. Virreinato peruano. Documentos para su historia. Colección de cartas de virreyes. Conde de la Monclova, 1699-1705, tomo III. Lima, 1955.

Pérez Mallaína, Pablo E. - Torres, Bibiano. La armada del Mar del Sur. Sevilla: CSIC, 1987.

Requena, Francisco. La defensa de las costas valencianas en la época de los Austrias. Alicante: Instituto de Cultura 'Juan Gil Albert', 1997.

Ribot, Luis. La monarquía de España y la guerra de Mesina (1674-1678). San Sebastián de los Reyes: Actas, 2002.

Rowlands, Guy. The Dynastic State and the Army under Louis XIV. Royal Service and Private Interest, 1661-1701. Cambridge: CUP, 2002.

Serrano Mangas Fernando. "La producción de la Fundición de la artillería de bronce de Sevilla en la segunda mitad del XVII". Archivo Hispalense, vol. 205 (1984), 38-47.

Storrs, Christopher. "El 'desastre' de Darien (1698-1700): la pervivencia del poder imperial español en el ocaso de la España de los Habsburgo". Revista de Historia Naval, vol. 68 (2000), 7-34.

Thompson, Irving A. A., Guerra y decadencia. Gobierno y administración en la España de los Austrias, 1560-1620. Barcelona: Crítica, 1981.

— "El declive de España y sus relaciones internacionales: percepciones y política a finales del siglo XVII". En Tiempo de Cambios. Guerra, diplomacia y política internacional de la Monarquía Hispánica (1648-1700), editado por Sanz Camañes, Porfirio. San Sebastián de los Reyes: Actas, 2012, 119-141.

Torres Ramírez, Bibiano. La Armada de Barlovento. Sevilla: CSIC, 1981.

Usunáriz, Jesús María. "Soldados, sociedad y política en un reino de frontera: Navarra siglos XVI y XVII". Iura Vasconiae, 4 (2007): 285-325.

Zapatero, Juan Manuel. Historia del castillo de San Lorenzo el Real de Chagre. Madrid: CEHOPU, 1985. 